\title{
"The Institutional Adjustment Margin to Import Competition: Evidence from Italian Minimum Wages"
}




\section{UBIREA \\ Institut de Recerca en Economia \\ Aplicada Regional i Pública \\ UNIVERSITAT DE BARCELONA}

WEBSITE: www.ub-irea.com•CONTACT: irea@ub.edu

\section{AQR}

Grup de Recerca Anàlisi Quantitativa Regional

Regional Quantitative Analysis Research Group

WEBSITE: www.ub.edu/aqr/•CONTACT: aqr@ub.edu

\section{Universitat de Barcelona}

Av. Diagonal, 690 • 08034 Barcelona

The Research Institute of Applied Economics (IREA) in Barcelona was founded in 2005, as a research institute in applied economics. Three consolidated research groups make up the institute: AQR, RISK and GiM, and a large number of members are involved in the Institute. IREA focuses on four priority lines of investigation: (i) the quantitative study of regional and urban economic activity and analysis of regional and local economic policies, (ii) study of public economic activity in markets, particularly in the fields of empirical evaluation of privatization, the regulation and competition in the markets of public services using state of industrial economy, (iii) risk analysis in finance and insurance, and (iv) the development of micro and macro econometrics applied for the analysis of economic activity, particularly for quantitative evaluation of public policies.

IREA Working Papers often represent preliminary work and are circulated to encourage discussion. Citation of such a paper should account for its provisional character. For that reason, IREA Working Papers may not be reproduced or distributed without the written consent of the author. A revised version may be available directly from the author.

Any opinions expressed here are those of the author(s) and not those of IREA. Research published in this series may include views on policy, but the institute itself takes no institutional policy positions. 
A growing body of research has contributed to understanding the labor market and political effects of globalization. This paper explores an overlooked aspect of trade-induced adjustments in the labor market: the institutional aspect. We take advantage of the two-tier collective bargaining structure of the Italian labor market, whereby the first tier entails setting minimum wages at the contract level. Using an instrumental variable strategy and exploiting variations in contract-level exposure to trade, we find for the 1995-2003 period that on average, the surge in imports decreased contractual minimum wages by $1.5 \%$. This impact increased with the increase in the share of unskilled workers employed under this contract. This negative institutional effect contrasts with a nonsignificant effect of trade on total wages, with the latter becoming positive and large only for highly skilled workers.

JEL Classification: J50, F16, J31, J24.

Keywords: bargained minimum wages; import competition; labor market institutions; skills.

Alessia Matano, Universitat de Barcelona and AQR. Email: amatano@ub.edu.

Paolo Naticchioni, University of Roma Tre, INPS-DCSR, IZA. Email:

p.naticchioni@gmail.com.

Francesco Vona, OFCE Sciences-Po and Université Côte d'Azur, SKEMA. Email: francesco.vona@sciencespo.fr.

We thank Italo Colantone and Rosario Crinò for kindly providing us the trade data. We also thank the research partnership between INAPP - Area Mercato del Lavoro (Rome) - and Dipartimento di Scienze Sociali ed Economiche - University of Rome "La Sapienza" - for access to the individual data. Alessia Matano also expresses her gratitude for the support received from Spain's Ministerio de Ciencia e Innovación through action ECO2016-75805-R. 


\section{Introduction}

In recent decades, institutions such as centralized bargaining, firing costs and minimum wages have been key to enhancing social protection, wage compression, and job security and stability (Card, 1996; Di Nardo et al., 1996). Historically, centralized wage bargaining and firing costs have been curbed in response to competitiveness concerns (Freeman and Gibbons, 1995). As suggested by Alesina and Giavazzi (2008), institutional changes aimed at reducing social protection may be the only viable solution to compete with countries whose social contracts entail a significantly lower degree of protection, especially for the least-skilled workers. However, the loss of social protection for the sake of international competition might lead unskilled and vulnerable workers in developed countries to embrace populistic political platforms (Autor et al, 2016, Colantone and Stanig, 2018), which could eventually establish an even less efficient and politically dangerous form of social protection (i.e., protectionism).

Theoretically, several papers have contributed to our understanding of the effect of skillbiased shocks, including technological change and the surge of massive economies such as China and India, on institutions. Acemoglu et al. (2001) model deunionization as a response to skill-biased technological changes reducing skilled workers' incentives to maintain a coalition with unskilled workers. Ebell and Haefke (2006) extend the seminal paper of Blanchard and Giavazzi (2003) to show that an increase in product market competition, including international competition (Mezzetti and Dinopoulos, 1991; Gaston and Trefler, 1995; Boulhol, 2009), acts as a discipline device to reduce quasi-rents and thus the scope of rent-sharing, which is the precondition for the existence of unions.

According to these models, endogenous institutional adjustments should amplify the inequality-enhancing effect of skill-biased shocks by reducing the bargaining power of unions (Blau and Kahn, 1996), but empirical support for this claim remains scant and indirect at best. A major difficulty in examining the endogenous institutional responses to skill-biased shocks is that institutions vary across rather than within countries, making it exceedingly difficult to identify the effect of skill-biased shocks on each institution.

Our paper contributes to filling this gap in the literature by taking advantage of the two-tier collective bargaining structure of the Italian labor market, whereby the first tier of bargaining entails setting minimum wages at the sector and occupation level. The second tier covers firmor local-level agreements to align wages to local productivity in a manner that provides 
incentives to workers engaged in production processes. ${ }^{2}$ Both first- and second-level bargaining might be affected by globalization and other skill-biased shocks. Unlike previous studies, which focus on the second tier of bargaining (Carluccio et al., 2015; Carluccio et al., 2016) and rent-sharing (Abowd and Lemieux, 1993), ${ }^{3}$ we examine the impact of globalization on the first institutional level, which is the core of collective bargaining. In particular, we focus on national contract minimum wages, which are a crucial part of the bargaining process in centralized wage regimes, such as those in Europe (Boeri and Burda, 2009). The idea is that such minima represent the main institutional feature ensuring social protection for the most vulnerable workers; thus, they are particularly suited to explain the recent political consequences of globalization.

We contribute to the active strand of literature on globalization's impact on the labor market in three ways (among others Autor et al., 2013; Autor et al., 2014). Above all, we are the first to estimate the effect of trade shocks on a specific labor market institution, namely, the minimum wages negotiated between trade unions and industrial representatives. Our data allow us to express total wages as the observable sum of the minimum wage and other additional wage components, including premia derived through the second tier of collective bargaining and premia associated with individual bargaining and bonuses, shedding light on the two margins of wage adjustment to trade shocks.

Second, we implement a well-established identification strategy to derive a causal effect that exploits exogenous variation in trade exposure for the same 3-digit sector in another country, the UK (Autor et al., 2013). To carry out the empirical analysis, we build a contractlevel measure of exposure to import penetration in which weights are derived from a large worker-level dataset that contains information on the sector and the national contract of each worker. These data allow us to determine sectoral exposure to import competition at the contract level.

Third, we differentiate the effect depending on workforce skills within a collective bargaining contract. Based on the assumption supported by the theoretical literature discussed above that a trade shock primarily decreases the outside options of unskilled workers, we expect the effect of trade on minimum wages to be an increasing function of the share of unskilled workers within contracts.

\footnotetext{
${ }^{2}$ Most European labor markets feature a similar two-tiered structure. Two excellent cross-country comparisons of the wage bargaining regime based on new datasets are those of De Caju et al. (2009) and Garnero et al. (2015). ${ }^{3}$ See also Brock and Dobbelaere (2006); Dumont et al. (2006); Boulhol et al. (2011); Dumont et al. (2012) and Matano and Naticchioni (2017).
} 
We find that wage adjustment occurs mainly through an institutional margin. In particular, minimum wages are negatively affected by higher exposure to import competition. The average cumulative decrease in minimum wages attributable to import competition is modest in absolute terms (-1.54\%), but it is relatively large compared to the increase in minimum wages over the time period considered $(+1.98 \%)$. Furthermore, this impact is, as expected, higher in national contracts with a greater share of unskilled workers. Importantly, for unskilled workers the stronger decline in the bargained minimum wage is not compensated for by a parallel increase in the decentralized/individual wage premium for unskilled workers. On the contrary, in contracts characterized by a high share of skilled workers, there is no significant reduction in the bargained minimum wage caused by import penetration and there is a significant increase in the decentralized wage premium, i.e., import competition implies a cumulative increase in total wages of between $1.2 \%$ and $2.1 \%$. Overall, these results highlight not only the expected inequality-enhancing effect of endogenous institutional adjustments but also a general increase in the labor market vulnerability of unskilled workers. Indeed, unskilled workers lose a portion of their "certainty equivalent" without receiving compensation in the form of an increase in the risky component of their earnings.

Recent empirical research on trade and wages has used labor market institutions as a fixed and exogenous mediating factor. ${ }^{4}$ The main recent references are Carluccio et al. (2015) for France and Felbermayr et al. (2014) for Germany. Exploiting the virtues of matched employeremployee datasets, both papers highlight the heterogeneous effects of trade on wages, depending on the bargaining regimes (i.e., sector- or firm-level) into which a company sorts itself. The closely related paper of Carluccio et al. (2016) examines the endogeneity of labor market institutions with respect to trade status but focuses on firm-level (second-tier) agreements. We extend and complement their work by estimating the impact of trade on the first tier of wage bargaining, which is most closely linked to the insurance role of labor market institutions.

The structure of the paper is as follows. Section 2 discusses the institutional background in greater detail. Section 3 presents the data and some descriptive evidence. Section 4 describes the identification strategy. Section 5 discusses the results. Section 6 presents the study's conclusions.

\footnotetext{
${ }^{4}$ There is a very broad literature on trade, offshoring and wage inequality. Benchmark references are Yeaple (2005), Verhoogen (2008), Grossman and Rossi-Hansberg (2008), Amiti et al. (2012), Helpman et al. (2017) and Harrigan and Reshef (2015). Additionally, recent theoretical models introduce a frictional labor market with centralized or decentralized wage bargaining (Helpman and Itskhoki, 2010; Felbermayr et al., 2012), but labor market institutions are not modeled as endogenous.
} 


\section{Institutional Background}

Italy is one of the few large countries within the European Union characterized by a relatively weak legal regulation of industrial relations. The main reference law, the so-called Statuto dei lavoratori of 1970, was not entered into the regulation of industrial relations, reflecting the view that social partners were the only actors in charge of establishing the rules of industrial relations, mainly through collective bargaining. This view has been maintained over time, and the industrial relations system in Italy remains unregulated by formal laws passed by the Government or the Parliament; instead, regulation is left to social partners.

According to this view, the Italian system of collective bargaining is centered on the role of the most representative employers and workers' organizations with the aim of establishing both the structure of collective bargaining and the regulation of national collective agreements. Two levels of collective bargaining were introduced in the Protocol of July 1993. The first one occurs at the industry-wide level (Contratto Collettivo Nazionale di Lavoro, CCNL), where working conditions and wage levels are fixed at the industry level via collective agreements between trade unions and employers' organizations. ${ }^{5}$ Collective bargaining is simply regulated by the general provisions of the civil code governing contracts and obligations. Formally, a collective agreement in Italy is binding only for the members of the union(s) signing the contract and the firm associates of employers' organizations. There is no explicit formal extension to other workers and firms. Nonetheless, in Italy, the wage floors (minimi tabellari) established in collective agreements may be used by labor courts as a reference to determine compliance with the provision of Art. 36 of the Italian Constitution, which states that "workers have the right to a remuneration commensurate to the quantity and quality of their work and in any case such as to ensure them and their families a free and dignified existence”. For this reason, minimum wages set in collective agreements are de facto extended to all workers, entailing a very high collective bargaining coverage that approaches $100 \%$ of workers (European Commission, 2014).

With respect to a statutory minimum wage system, the Italian system sets minimum wages for all occupations within a given CCNL contract. Thus, minima are set not only for low-paid

\footnotetext{
${ }^{5}$ Note that the choice of the industry definition of the CCNL is left to the unions and employer representatives, and it is not strictly related to standard classifications such as NACE, which implies that for some NACE codes (at the 2- or 3-digit levels), there might be various reference national contracts. For instance, within the same NACE code, there might be different contracts for small, medium, and large firms or for craft firms. This difference contributes to explaining the imperfect overlapping of CCNL and NACE classes shown in Section 3.
} 
workers but also for high-paid workers such as managers and professionals. Nonetheless, while each CCNL may contain both high- and low-skilled occupations, bargaining between unions and employer representatives is not necessarily homogenous across different occupations (livelli di inquadramento). In each renewal of a CCNL, the social parties might decide that the wage increase bargained for unskilled occupations is greater than the wage increased bargained for high-skilled occupations, or vice versa. Therefore, the relevant level of negotiation for the setting of wage floors is the CCNL-by-occupation level, which is the level we consider in this paper.

Whereas the first level of collective bargaining is aimed mostly at maintaining worker purchasing power over time, decentralized (company or regional) collective bargaining is linked to productivity and firms' economic performance. ${ }^{6}$ Interestingly, the second tier of collective bargaining has always been subordinated to the national level, and its diffusion has been fairly limited to the largest firms and the northern regions. Second-level bargaining is not compulsory, and it is subject to the in melius or favorability principle: that is, wages and working conditions cannot be worse than those agreed to at the industry level. ${ }^{7}$ Importantly, the observed wage variability within a CCNL-by-occupation level does not depend only on decentralized bargaining, since all firms can engage in individual bargaining in melius with respect to the CCNL, even without a second-level collective bargaining contract.

In recent years, the collective bargaining system has revealed the progressive erosion of trade unions and employer associations' representativeness, increasing noncompliance with collective bargaining minimum wages and the emergence of 'pirate contracts' signed by nonrepresentative social partners (Lucifora and Naticchioni, 2018). Nonetheless, these issues will be not examined in this paper because data limitations allow us to cover only the 19952003 period. Nevertheless, this is an advantage for our analysis, as the years covered by our data can be considered a period of relative stability for the system of industrial relations introduced in 1993, with a much lower incidence of noncompliance and pirate contracts compared to more recent years (Garnero et al, 2015).

One concern is that our analysis does not consider the surge of China, which has been identified as the main driver of structural and political changes in the US (Autor et al., 2013;

\footnotetext{
${ }^{6}$ Note that the national-level contract is bargained between sectoral social partners' federations, i.e., trade unions and employers' organizations, while firm- or local-level bargaining is conducted mainly by the unitary union representative body (Rappresentanze sindacali unitarie or RSU) elected in work councils.

${ }^{7}$ To give an idea of the diffusion of second-level bargaining, according to RIL-AIDA data (from INAPP, Italian Institute for Public Policy Analysis), only 3-4\% of firms were involved in second-level bargaining aimed at increasing wages in the years 2010 and 2014.
} 
Autor et al., 2016). However, following the introduction of the Euro, European countries experienced an important shock immediately prior to China's 2001 entry to the WTO. In Italy, the introduction of the Euro occurred de facto in 1997 with the re-entry of the Lira to the European Monetary System. ${ }^{8}$ For the large Italian manufacturing sector, the Euro represented a critical turning point by stopping the series of competitive devaluations that had been used repeatedly in the 1980s and early 1990s to preserve international competitiveness (Basile, 2001). ${ }^{9}$

\section{Data and Descriptive Evidence}

The main data source for this paper is the Italian administrative database provided by the Italian National Social Security Institute (INPS). The database follows individuals born on the 10th of March, June, September and December, and therefore, it is a representative sample of approximately of $1 / 90^{\text {th }}$ of the working population. It is a matched employer-employee dataset that was constructed for the 1995-2003 period by merging the INPS employee information with the INPS employer information database. For firms, the dataset contains the following information: the plant location (province), the number of employees and the main 3-digit sector of the activity. For workers, the available characteristics are age, gender, occupation (whitecollar, blue-collar, and managers), the dates of the beginning and end of the current contract (if any), worker status (part-time or full-time), real gross yearly wage, and the number of months, weeks and days worked.

The key advantage of this dataset is that it contains information about the main national contract of the employee (CCNL) together with the occupation level ('ivello di inquadramento') in each major contract. Beginning in 2005, this information was no longer collected by INPS, and we use the most recent matched employer-employee dataset containing information on national contracts and occupations, which was released in 2003. As discussed above, since wage adjustments within a major CCNL contract can be heterogeneous across occupation levels, our unit of analysis is defined at the level of the contract-occupation minimum wage. ${ }^{10} \mathrm{We}$ retrieve information about bargained minimum wages for each (national)

\footnotetext{
${ }^{8}$ Italy reentered the European Monetary System at the end of 1996 with the limited possibility to fluctuate with respect to the ECU, and on January 1, 1999, the exchange rate between the Lira and the Euro was set at its irrevocable level.

${ }^{9}$ Previous studies found that the introduction of the Euro represented an important shock for Italian companies, forcing them to adapt their workforce composition and organizational practices to international standards (Bugamelli et al., 2010; Raitano and Vona, 2017).

${ }^{10}$ To focus on a homogenous sample of contracts, we drop the few contracts that are not present throughout the time span of our analysis (approximately $2.4 \%$ of observations are dropped).
} 
contract-occupation level from the National Council for Economics and Labour (CNEL) archives.

We limit our analysis to private employees in the manufacturing sector, which is the sector with the greatest exposure to trade shocks. We consider both part-time (converted into fulltime equivalent) and full-time workers aged between 15 and 64 (in their first year in the sample). Moreover, we drop workers without information on the minimum wage $(23 \%) .{ }^{11} \mathrm{We}$ clean the data further by dropping both missing observations in our variables of interest and extreme observations for which the real weekly wage is above (below) the $99^{\text {th }}$ (1st) wage percentile. We end up with 315,939 worker-year observations for 64,328 workers. We finally collapse the dataset by contract-occupation and year to obtain our estimation sample composed of 1,782 observations for 198 contract-occupation levels over the 1995-2003 period.

Both the annual minimum wage and the (full-time equivalent) worker average annual wage by contract-occupation have been deflated using the consumer price index (FOI index "Indice dei prezzi al consumo per le famiglie di operai e impiegati" -ISTAT, base year 2002). Annual minimum and average wages in real terms are our main dependent variables.

The main variable of interest is import competition. In line with the vast literature on the labor market impact of trade (e.g., Guadalupe, 2007; Bugamelli et al., 2010), we use import over turnover to measure import competition. We use data on total imports from Eurostat COMEXT defined at the 3-digit sector level ${ }^{12}$ for Italy and the UK, and data on turnover from Eurostat are available at the 3-digit level from 1995 onward.

A key step of our empirical analysis is to build a measure of exposure to import competition for each detailed national contract-occupation. The idea is to exploit the relevance of each sector within each contract-occupation. While Italian national contracts are mostly defined within broad sectoral categories, one specific contract might be used in different 3-digit sectors. Table 1A of the Appendix shows that only 9\% of contract-occupations are present in one 3digit sector. We define the index of exposure to import competition by national contractoccupation as follows:

$$
I m p_{c t}=\sum_{s=1}^{S}\left(\frac{\text { Imports }}{\text { Turnover }}\right)_{s t} \times \frac{L_{c s t}}{L_{c t}}
$$

\footnotetext{
${ }^{11}$ We have data on minimum wages for all occupations within the 28 major national contracts, which cover $77 \%$ of workers and that are relatively more concentrated in larger firms.

${ }^{12}$ Sectors are defined according to the Nace rev1.1 classification for 86 manufacturing sectors.
} 
where $c$ refers to the contract-occupation, $s$ refers to the 3-digit sector and $t$ refers to time. The index is the weighted average of total imports over turnover at the sector level, with weights $L_{c s t} / L_{c t}$ reflecting the relative presence of the sector within a specific national contractoccupation. In particular, they are computed as the number of contract/occupation-sector-year workers over the number of contract/occupation-year workers. In an extension of the analysis, we also explore the effect of ICT investments on minimum wages by building a similar measure of exposure using EU-KLEMS data.

Table 1 shows the descriptive statistics, weighted by the time-average number of workers in each contract-occupation, of the variables used in the analysis. The average annual minimum wage is 15,011 , while the average (gross) annual wage is approximately 20,638 Euros. Their ratio $(0.73)$ is quite similar to the Kaitz index of 0.75 (the ratio of minimum to median wages) computed for the same sample. This high Kaitz index is a peculiar feature of the Italian labor market. ${ }^{13}$ For the other variables, the average age by contract-occupation is 36 . In addition, contracts are composed of $25 \%$ white-collar workers and managers (75\% blue-collar workers), while the relative presence of females is $32 \%$, and the median firm size by contract-occupation is $74 .{ }^{14}$ Finally, the average value of imports over turnover is $22 \%$, which is consistent with our focus on the manufacturing sector.

[Table 1 about here]

Column 3 displays the growth rates for each variable. Both average and minimum wages are relatively stagnant over time (see also Figure 1), contrasting with a sharp increase of import exposure by $23.3 \%$ (Figure 2), which is also associated with the currency reevaluation induced by the adoption of the Euro in 1997 (see Bugamelli et al., 2010) and the large increase in ICT capital investments. Overall, the freezing in the increase of minimum and annual wages can be explained by the worsening Italian competitiveness during the time period of our analysis. The remainder of the paper explores this hypothesis, attempting to isolate a particular driver of wage stagnation: the surge in import competition.

[Figure 1 about here]

\footnotetext{
${ }^{13}$ Garnero et al. (2015) report the Kaitz index for 17 EU countries for more recent years around 2010. The Italian index is the highest at 0.9 , while the cross-country average is 0.55 .

${ }^{14}$ The median firm size is higher than that computed in the raw data because the larger national contracts used in our analysis are overrepresented in larger firms. Large firms are the main firms involved in international trade (Bernard et al., 2003), i.e., they represent the group of firms in which we are interested.
} 
[Figure 2 about here]

\section{Empirical Strategy}

In this section, we detail the empirical strategy used to estimate the impact of import competition on the minimum wages and average wages of Italian workers. By comparing the two effects, we shed light on the institutional margin of adjustment to trade shocks. We estimate the following equation:

$$
\ln \left(w_{c t}\right)=\alpha+\Psi^{\prime} X_{c, t-2}+\beta \ln \left(\operatorname{Im} p_{c, t-2}\right)+\varphi_{c}+\lambda_{t}+\varepsilon_{c t}
$$

where $c$ indexes the contract-occupation and $t$ time, $\varepsilon_{c t}$ is a standard error term, and $X_{c, t-2}$ is the set of additional controls described in Table 1. Contract-occupation $\left(\varphi_{c}\right)$ and time $\left(\lambda_{t}\right)$ fixed effects are included to purge our estimates from the influence of unobservable contract characteristics and macroeconomic shocks, respectively. $\ln \left(w_{c t}\right)$ is either the annual minimum wage or the annual average wage, both in logarithm and in real terms. The main variable of interest $\ln \left(\operatorname{Im} p_{c, t-2}\right)$ is the 2-year lagged import penetration in the logarithm.

The choice of the two-year lag is motivated by institutional considerations; in Italy, the average length of a collective agreement is two years (De Caju et al., 2009). If a new negotiation on minimum wages begins immediately after the previous contract is signed, the social parties' relevant information for establishing the basis of a new agreement is the level of import intensity at the beginning of the negotiation, that is, at $t-2$. This choice also reflects the fact that import data are available with at least a one-year delay to social parties and thus that information about imports at $t-2$ is relevant at $t-1$, the crucial negotiation phase for the renewal of the contract. Furthermore, to add weight to larger contracts, our estimates are weighted by the time average of the number of workers belonging to a specific contractoccupation. Standard errors are clustered at the national contract-occupation level.

In section 5, we show the robustness of our results to different lag structures, weighting schemes and clustering levels. Moreover, we discuss in detail two extensions to equation 1, including either an additional skill-biased shock (ICT capital) or allowing the effect of imports to be heterogeneous depending on the skill level of the contract.

One issue that must be considered in our analysis is endogeneity, which may arise for at least two reasons. First, there could be an issue of reverse causality. For instance, an increase 
in domestic wages in Italy could push up the wages bargained at the sectoral levels, and for this reason, firms might have incentives to source more inputs and/or final products from abroad, substituting for higher labor costs with cheaper imports/final products, which would lead to an upward bias in the OLS estimates.

Second, an omitted variables issue might occur, i.e., unobserved shocks might induce a correlation between changes in the wages settled in collective bargaining and changes in imports. For instance, negative supply shocks in Italy may reduce bargained wages while increasing imports, as domestic suppliers become less productive and competitive than foreign suppliers, which would induce a downward bias in the OLS estimates.

As a first step to mitigate these two issues, we include the endogenous variable - import penetration in logs - with a lag of 2 years. Nevertheless, the problem of persistent and serially correlated shocks and persistent trends of the dependent and endogenous variables may be mitigated but not entirely solved by using lagged variables.

A more compelling way to tackle this issue is to use an instrumental variable approach that became standard in the trade literature following the seminal contribution of Autor et al. (2013). ${ }^{15}$ More specifically, we instrument the 2-year lagged import penetration in contractoccupation $c$ using the corresponding import variable computed for the UK:

$$
\operatorname{IVImp} p_{c, t}=\sum_{S=1}^{S}\left(\frac{\text { Imports } U K}{\text { Turnover } U K}\right)_{s, t} \times \frac{L_{c, s, t=1995}}{L_{c, t=1995}}
$$

We fix the employment weights in 1995 to mitigate the simultaneity bias associated with the fact that contemporaneous employment is also affected by import competition. Notice that because our endogenous variable is included with a 2-year lag, the first year of our estimate is 1997. This mitigates concerns about the presence of a simultaneity bias and anticipated trade effects on wages.

This kind of shift-share instrument is intended to isolate variation in import penetration caused by exogenous changes in supply in the origin countries (e.g., China), uncorrelated to domestic supply and demand shocks. The key identifying assumption is that domestic demand and supply shocks in the UK are uncorrelated with those in Italy, which is consistent with the

\footnotetext{
15 Other examples of studies using this approach are Dauth et al. (2014); Hummels et al. (2014); Bloom et al. (2016); Colantone et al. (2015); and Colantone et al (2018).
} 
well-known fact that the correlation between the UK and the EU business cycles is weaker than the correlation between the UK and the US business cycles (Artis et al., 2004).

\section{Results}

\subsection{Baseline Results.}

Table 2 shows the results of the estimation of equation 1. Columns (1) to (3) present the estimates in which the dependent variable is the minimum wage. The first main result of our paper is that, as expected, an increase in import competition decreases the minimum wage in national contracts in a statistically significant way. ${ }^{16}$ The elasticity of minimum wages to trade is small $(-0.014$, column (1)) but significantly higher (-0.066) when we apply our favorite IV strategy (column 2), suggesting that the OLS coefficients are downwardly biased.

\section{[Table 2 about here]}

Column (3) reveals that the point estimate remains statistically significant at a conventional level when we add the covariates by national contract-occupation described in Table 1, namely, the shares of white-collar workers and female workers, the average age of the worker (a proxy of experience) and the log of the median firm size (a proxy for both productivity and market power). However, we observe a drop of almost $20 \%$ in the estimated coefficient, which implies that part of the total import effect occurs through induced compositional changes within each contract-occupation. According to previous literature (e.g., Lu and Ng, 2013; Consoli et al., 2016; Colantone et al, 2018), the main compositional effect is a skill upgrading associated with the fact that an increase in international competition forces companies to improve the quality of their products and therefore that of their workforce. Our data support this interpretation: the share of white-collar workers and managers in a contract is positively correlated with both the import competition (0.20) and the minimum wage level (0.71).

Columns (4) to (6) replicate the analysis using the average wage by contract as the dependent variable. In all of the specifications, the effect of import penetration on wages is not statistically significant at conventional levels. The lack of an effect on manufacturing wages is consistent with the balancing of two forces (Autor et al., 2013): on the one hand, there is a decline in the demand of manufacturing jobs induced by import penetration that implies a downward pressure

\footnotetext{
${ }^{16}$ A standard F-test on the instrument strength is reported at the bottom of each table. The test largely passes the cut-off value of 10 , which is considered the rule-of-thumb for a strong instrument.
} 
to wages; on the other hand, there is an upgrading of the workforce skills through a selection effect. This result reinforces our main finding: the institutional margin is the main margin through which wages adjust to import competition in countries such as Italy that are characterized by a two-tiered wage bargaining system. ${ }^{17}$

In the Appendix, we also show that our results are robust to small variants of our main specification. First, we explore a different specification of the lag structure for the explanatory variables, that is, a one-year lag rather than a two-year lag (Table A2). Second, we use the main national contract (28) as a cluster unit to account for any form of correlation across the occupation-level contracts within a major contract (Table A3). Finally, we weigh our estimate for the number of worked weeks rather than for the number of workers (Table A4).

\subsection{Extensions.}

Our results are broadly consistent with those of Boulhol et al. (2011) for the UK and Dumont et al. (2006) for five large EU countries. However, while in these papers, the adjustment margin is on the workers' bargaining power over the variable quasi-rents of the matching, our analysis highlights an adjustment that occurs through a renegotiation of fixed wage floors defined in the collective bargaining. Since wage floors represent the insurance component of wages, their levels are relatively more important for the welfare of risk-averse workers than for the share of quasi-rents. This remark is particularly salient for less-skilled workers because of their exposure to other skill-biased shocks such as automation and because the wage floors represent the bulk of their total earnings.

Based on these insights, there are two natural extensions of our analysis. First, we study the heterogeneous effect that depends on the skill level of the contract (as suggested in Dumont et al., 2012). Second, we analyze the effect of technology shocks, which, together with trade, may have also affected wage bargaining institutions (Acemoglu et al., 2001).

The first extension consists of adding to equation (1) the interaction between the index of import penetration and the share of white-collar workers and managers within each contractoccupation. ${ }^{18}$ Results are presented in Table 3 and plotted in Figures 3 and $4 .{ }^{19}$

\footnotetext{
${ }^{17}$ To investigate whether our main result captures a long- rather than a short-term relation, we re-estimate equation (1) for a long time horizon, replacing our variables of interest with their 1995-2003 growth rates. Our main findings are confirmed and estimates are available upon request.

${ }^{18}$ We use the share of white-collar workers and managers in the contract as proxy for skills because the occupational levels ("livello di inquadramento") within the contract are not defined in a consistent way across contracts. It is also difficult to use the CNEL data on contracts to infer an exact skill ranking based on occupational levels.

19 The results presented in Table 3 are unaffected using a one-year time lag, different clustering methods and regression weights. These estimates are available upon request.
} 
[Table 3 about here]

[Figure 3 about here]

[Figure 4 about here]

First, notice that the positive association between skill upgrading and changes in the minimum wage is statistically significant at the conventional level. Looking at the effect of trade on minimum wages, columns (1)-(3) show that while the baseline effect remains negative and higher in magnitude compared to previous estimates, the interaction with the skills share is positive and significant at the $1 \%$ level. ${ }^{20}$ Thus, as the share of skilled workers in the national contract-occupation increases, the negative effect of trade on minimum wages is significantly mitigated. Using our preferred specification in column 2 , this effect remains negative and statistically significant until the $84^{\text {th }}$ percentile of skill intensity. As is clear from Figure 3, which plots the derived marginal effects, above that percentile, the effect is not significantly different from zero.

Looking at the effect of trade on average wages (columns 4 to 6), the baseline effect is negative and not statistically significant, while the interaction terms are positive and statistically significant in the IV specifications (columns 5 and 6). Combining the baseline effect with that mediated by skills, the effect of trade becomes positive and significant above the $85^{\text {th }}$ percentile (equivalent to a share of white-collar workers of 0.58 ) of the contracts' skill share distribution: for these high-skilled contract-occupations, international competition leads to a statistically significant increase in average wages (see Figure 4).

The second extension explores the impacts of both ICT and trade on minimum wages. To account for exposure to technological change at the contract-occupation level, we use EUKLEMS data on sectoral ICT investment over value added at the 2-digit level. For the sake of consistency, we use ICT investment in the UK as an instrument and build the contractoccupation level exposure as for trade. Both measures are computed in the same way as for trade.

\footnotetext{
${ }^{20}$ The use of two-year lags for all the explanatory variables to mitigate concerns over potential endogeneity in the share of white-collar workers and managers. As an alternative way to check the robustness of our results, we also estimate the model fixing this share at the beginning of the period for the specifications in columns 1-2 (Table 3), but without being able to estimate the baseline effect of the share of white-collar workers and managers. The results are unchanged and are available upon request.
} 
Table 4 summarizes the main results of this extension, focusing on the two critical specifications: 1) with all controls; 2) with all controls plus the interaction term between skills and imports. Our main results for the impact of trade are confirmed, while the diffusion of ICT technologies has a positive but not significant impact on bargained wage floors that becomes statistically significant in the specifications with the interactions term.

\section{[Table 4 about here]}

\subsection{Discussion.}

This section discusses the magnitude of the estimated effects. Over the entire period of our analysis, the share of import over turnover increases by $23.3 \%$. In the absence of such an increase in import penetration, minimum wages in real terms would have grown by an additional $1.54 \%$, according to our preferred IV estimate in Table 2, column (2). ${ }^{21}$ In relative terms, the effect is large, representing $78 \%$ of the modest increase in the minimum wage between 1995 and 2003 (1.98\%, see Table 1). In sum, the magnitude of the estimated effect is economically meaningful and highlights the inequality-enhancing effect of endogenous institutional adjustments.

Most importantly for relative comparison, our results underscore highly heterogeneous effects across skill groups. The results are illustrated in Figures 3 and 4, which plot the estimated elasticities shown in columns (2) and (5) of Table 3, with 95\% confidence intervals, along the percentiles of the white-collar share distribution. For minimum wages (Figure 3), the elasticity ranges from -0.071 ( 5 th percentile) to $0.020\left(95^{\text {th }}\right.$ percentile). For total wages (Figure 4), the corresponding elasticities are -0.016 and 0.090 . A visual inspection of these figures shows that for both minimum wages and total wages, the magnitude of the effects changes substantially around the $85^{\text {th }}$ percentiles of skill intensity. In cumulative terms, the increase in trade exposure induced a $1.7 \%$ loss in minimum wages in contracts characterized by the highest share of unskilled workers ${ }^{22}$ but no (statistically) significant losses for contracts characterized by a share of skilled workers above the $84^{\text {th }}$ percentile. A similar pattern emerges for total wages where the positive and significant effect above the $85^{\text {th }}$ percentile of the skilled share distribution implies a cumulative increase in wages over the time period considered from $1.2 \%$

\footnotetext{
${ }^{21}$ The $1.54 \%$ decrease is obtained by multiplying the elasticity of minimum wages, i.e., -0.066 (column (2) of Table 2), and the long-term change in import competition, i.e., $23.3 \%$.

${ }^{22}$ For the cumulative effect, we refer to the impact computed over the whole period, which is obtained by multiplying the elasticity of minimum wages for the unskilled workers, i.e., - 0.072 (column (2) of Table 3), with the long-term change in import competition, i.e., $23.3 \%$.
} 
for contracts at the $86^{\text {th }}$ percentile of the skill share distribution to $2.1 \%$ for those at the $95^{\text {th }}$ percentile, ${ }^{23}$ while no significant effect is detected below the $86^{\text {th }}$ percentile of the skill share distribution.

The comparison of these effects reveals that risk-averse unskilled workers are the worst off in a hypothetical risk-reward plane. Indeed, the nonfixed earnings component does not compensate for the decrease in fixed minimum wages, increasing the vulnerability of lowskilled workers. However, contracts with a high share of skilled workers do not experience a significant reduction in the fixed wage and enjoy a significant increase in the nonfixed wage premium that is attributable either to individual bargaining or to decentralized collective bargaining at the firm/local level. We argue that the joint effect of widening the skill gap, increasing vulnerability and uncompensated earnings losses might help explain unskilled workers' turn toward populistic political parties (Autor el al., 2016; Colantone and Stanig, 2018).

Furthermore, the shock analyzed in this paper is relatively small compared to the dramatic increase in Chinese imports after 2003. If labor market institutions respond linearly to shocks, the size of the effects estimated here will increase substantially. In the presence of larger and persistent shocks, however, other adaptation margins are likely to become more important, notably, an increase in noncompliance rates (such as that documented in Garnero et al., 2015) and the endogenous introduction of pirate contracts aimed at reducing labor costs in areas and industries characterized by suffering labor markets (Lucifora and Naticchioni, 2018). While these important research questions about more recent trends are left for future research, our paper underlines that the effects of trade on collective bargaining were already at work in the period investigated and proposes a simple approach to address them.

\section{Conclusions}

This paper contributes to the literature by investigating an issue that has been generally neglected: the impact of import penetration on domestic labor market institutions, particularly on the minimum wages settled in the collective bargaining system. We exploit a unique feature of the Italian bargaining system by taking advantage of the two-tier bargaining structure of the Italian labor market whereby the first tier of bargaining entails setting minimum wages at the sector and occupation levels to estimate the contract-level response of such minima to trade

\footnotetext{
${ }^{23}$ These effects are obtained by multiplying the elasticity of total wages at the various point of the skill share distribution (5\% at the 86th percentile and $9 \%$ at the 95th percentile) with the long-term change in import competition, i.e., $23.3 \%$.
} 
shocks. As is now customary in the literature (Autor et al., 2013), we retrieve causal effects that use trade exposure in another country (the UK in our case) to isolate the exogenous variation in import penetration.

Three main findings stand out from our analysis. First, wage adjustment occurs mainly through an institutional margin: minimum wages settled in collective bargaining are negatively affected by higher exposure to import competition. Second, the institutional effect contrasts with no effects of trade shocks on total wages, except for contracts with a high share of skilled workers, for which the effect is positive and statistically significant. Third, our results highlight the increased labor market vulnerability for unskilled workers since the reduction in the minimum wage in unskilled-intensive contracts not only is larger than in skill-intensive contracts but also is not offset by a parallel increase in the decentralized wage premium.

We leave to future research the analysis of the timing of the effects on labor market institutions (which, due to data availability, is limited to the medium term in our study) and of political outcomes. It is possible that the effect of imports on minimum wages depend nonlinearly on the size and the persistency of the trade shock. At the same time, the documented incidence of pirate contracts and noncompliance might be explained by skill-biased shocks. 


\section{References}

1. Abowd J., Lemieux T., 1993. The effects of product market competition on collective bargaining agreements: The case of foreign competition in Canada, Quarterly Journal of Economics, vol. 108(4), pp. 983-1014.

2. Acemoglu, D., Aghion, P. and Violante, G.L., 2001. Deunionization, technical change and inequality. In Carnegie-Rochester conference series on public policy, Vol. 55, No. 1, pp. 229-264.

3. Alesina, A. and Giavazzi, F., 2008. The future of Europe: reform or decline. Mit Press, Cambridge.

4. Amiti M., Cameron L., 2012. Trade Liberalization and the Wage Skill Premium: Evidence from Indonesia, Journal of International Economics, vol. 87(2), pp. 277-287.

5. Artis M., Hans-Martin K., Toro J., 2004. The European Business Cycle. Oxford Economic Papers, 56, 1-44.

6. Autor D., Dorn D., Hanson G., Song J., 2014. Trade Adjustment: Worker Level Evidence, The Quarterly Journal of Economics, vol. 129(4), pp. 1799-1860.

7. Autor, D., Dorn, D., Hanson, G. and Majlesi, K., 2016, Importing Political Polarization? NBER Working Paper 22637.

8. Autor, D., Dorn, D., Hanson, G.H., 2013. The China syndrome: Local labor market effects of import competition in the US. American Economic Review, 103(6), pp.2121-68.

9. Basile, R., 2001. Export behaviour of Italian manufacturing firms over the nineties: The role of innovation. Research Policy, 30(8), 1185-1201.

10. Bernard, A., Jensen, J., Redding, S. and Schott, P., 2007. Firms in international trade. Journal of Economic perspectives, 21(3), pp.105-130.

11. Blanchard, O., Giavazzi, F. 2003. Macroeconomic effects of regulation and deregulation in goods and labor markets, Quarterly Journal of Economics, vol. 118(3), pp. 879-907.

12. Blau, F.D. and Kahn, L.M., 1996. International differences in male wage inequality: institutions versus market forces. Journal of Political Economy, 104(4), pp.791-837.

13. Bloom, N., Draca, M., and Van Reenen, J. 2016. Trade induced technical change? The impact of chinese imports on innovation, IT and productivity. Review of Economic Studies, 83(1):87-117.

14. Boulhol, H., 2009. Do capital market and trade liberalization trigger labor market deregulation? Journal of International Economics, 77(2), pp.223-233.

15. Boulhol, H., Dobbelaere, S. and Maioli, S., 2011. Imports as product and labour market discipline. British Journal of Industrial Relations, 49(2), pp.331-361.

16. Brock, E. and Dobbelaere, S., 2006. Has international trade affected workers' bargaining power?. Review of World Economics, 142(2), pp.233-266.

17. Bugamelli M., Schivardi F., Zizza R., 2010. The Euro and Firm Restructuring, NBER Chapters, in: Europe and the Euro, pp. 99-138 National Bureau of Economic Research.

18. Card, D., 1996. The effect of unions on the structure of wages: A longitudinal analysis. Econometrica 1, pp.957-979.

19. Carluccio, J., Fougere, D. and Gautier, E., 2015. Trade, wages and collective bargaining: Evidence from France. The Economic Journal, 125(584), pp.803-837.

20. Carluccio, J., Fougère, D. and Gautier, E., 2016. The impact of trade shocks on collective wage bargaining agreements, CEPR discussion paper 11289

21. Caselli, M., Fracasso, A. and Traverso, S., 2018. Globalization and Electoral Outcomes: Evidence from Italy, DEM working paper.

22. Colantone, I. and Crinò, R. 2014. New imported inputs, new domestic products. Journal of International Economics, 92(1):147-165. 
23. Colantone, I. and Stanig, P., 2018. The trade origins of economic nationalism: Import competition and voting behavior in Western Europe. American Journal of Political Science, 62(4), pp.936-953.

24. Colantone, I., Matano, A., Naticchioni, P. (2018), New Imported Inputs, Wages and Worker Mobility, Baffi-Carefin Working Paper No. 2018-77.

25. Consoli, D., Vona, F. and Rentocchini, F., 2016. That was then, this is now: Skills and Routinization in the 2000s. Industrial and Corporate Change, 25(5), pp.847-866.

26. Dauth, W., Findeisen, S., and Suedekum, J. (2014). "The rise of the East and the Far East: German labor markets and trade integration". Journal of the European Economic Association, 12(6):1643-1675.

27. DiNardo, F. and Fortin, N.M., Lemieux, T. 1995. Labor market Institutions and the distribution of wages, 1973-1992. A semiparametric approach. Econometrica, 64, p.100101044.

28. Du Caju, P., Gautier, E., Momferatou, D. and Ward-Warmedinger, M., 2009. Institutional features of wage bargaining in 23 European countries, the US and Japan Ekonomia, vol. 12(2). pp. 57-108.

29. Dumont, M., Rayp, G. and Willemé, P., 2006. Does internationalization affect union bargaining power? An empirical study for five EU countries. Oxford Economic Papers, 58(1), pp.77-102.

30. Dumont, M., Rayp, G. and Willemé, P., 2012. The bargaining position of low-skilled and high-skilled workers in a globalising world. Labour Economics, 19(3), pp.312-319.

31. Ebell, M. and Haefke, C., 2006. Product market regulation and endogenous union formation (No. 2222). IZA Discussion Papers.

32. Felbermayr, G., Hauptmann, A. and Schmerer, H.J., 2014. International trade and collective bargaining outcomes: Evidence from German employer-employee data. The Scandinavian Journal of Economics, 116(3), pp.820-837.

33. Felbermayr, G., Prat, J. and Schmerer, H.J., 2011. Globalization and labor market outcomes: Wage bargaining, search frictions, and firm heterogeneity. Journal of Economic theory, 146(1), pp.39-73.

34. Freeman, R.B. and Gibbons, R.S., 1995. Getting together and breaking apart: the decline of centralized collective bargaining. In Differences and Changes in Wage Structures (pp. 345-370). University of Chicago Press.

35. Gaston, N. and Trefler, D., 1995. Union wage sensitivity to trade and protection: theory and evidence. Journal of International Economics, 39(1-2), pp.1-25.

36. Garnero, A., Kampelmann, S. and Rycx, F., 2015. Sharp Teeth or Empty Mouths? E uropean Institutional Diversity and the Sector $\square$ Level Minimum Wage Bite. British Journal of Industrial Relations, 53(4), pp.760-788.

37. Grossman, G.M. and Rossi-Hansberg, E., 2008. Trading tasks: A simple theory of offshoring. American Economic Review, 98(5), pp.1978-97.

38. Guadalupe, M., 2007. Product market competition, returns to skill, and wage inequality. Journal of Labor Economics, 25(3), pp.439-474.

39. Hummels, D., Jørgensen, R., Munch, J., and Xiang, C. (2014) "The wage effects of offshoring: evidence from Danish matched worker-firm data". American Economic Review, 104(6):1597-1629.

40. Harrigan, J. and Reshef, A., 2015. Skill $\square$ biased heterogeneous firms, trade liberalization and the skill premium. Canadian Journal of Economics/Revue canadienne d'économique, 48(3), pp.1024-1066.

41. Helpman, E., Itskhoki, O., Muendler, M.A. and Redding, S.J., 2017. Trade and inequality: From theory to estimation. The Review of Economic Studies, 84(1), pp.357-405. 
42. Helpman, E. and Itskhoki, O., 2010. Labour market rigidities, trade and unemployment. The Review of Economic Studies, 77(3), pp.1100-1137.

43. $\mathrm{Lu}, \mathrm{Y}$. and $\mathrm{Ng}, \mathrm{T}$., 2013. Import competition and skill content in US manufacturing industries. Review of Economics and Statistics, 95(4), pp.1404-1417.

44. Matano, A. and Naticchioni, P., 2017. The extent of rent sharing along the wage distribution. British Journal of Industrial Relations, 55(4), pp.751-777.

45. Mezzetti, C. and Dinopoulos, E., 1991. Domestic unionization and import competition. Journal of international Economics, 31(1-2), pp.79-100.

46. Raitano, M. and Vona, F., 2017. Competition, firm size and returns to skills: Evidence from currency shocks and market liberalisations. The World Economy, 40(12), pp.2676-2703.

47. Verhoogen E., 2008. Trade, Quality Upgrading, and Wage Inequality in the Mexican Manufacturing Sector, Quarterly Journal of Economics, vol. 123(2), pp. 489-530.

Yeaple S., 2005. A simple model of firm heterogeneity, international trade, and wages, Journal of International Economics, vol. 65(1), pp. 1-20. 


\section{Tables and Figures}

\begin{tabular}{lrrr}
\hline Table 1: Descriptive statistics & & & \\
\hline & Mean & Std.Dev. & Growth Rate \% \\
\hline Variables & & & \\
\hline Real annual minimum wage & 15,011 & 2,749 & 1.98 \\
Real annual total wage & 20,638 & 8,721 & 1.81 \\
Import penetration (import over turnover) & 0.222 & 0.100 & 23.34 \\
Share of white-collar workers and managers & 0.254 & 0.292 & 1.17 \\
Share of female & 0.316 & 0.203 & 13.48 \\
Mean age & 36 & 4 & 5.54 \\
Firm size & 74 & 204 & 0.12 \\
ICT capital over value added & 0.024 & 0.006 & 26.44 \\
\hline
\end{tabular}

Notes: Statistics weighted by the time-average number of workers for each contract-occupation. Growth rates are long-term (1995-2003).

Table 2: Impact of imports on wages

\begin{tabular}{|c|c|c|c|c|c|c|}
\hline & \multicolumn{3}{|c|}{ Log Minimum Wage } & \multicolumn{3}{|c|}{ Log Total Wage } \\
\hline & (1) & $(2)$ & (3) & $(4)$ & $(5)$ & (6) \\
\hline & FE & IVFE & IVFE & FE & IVFE & IVFE \\
\hline 2-Lag log import penetration index & $\begin{array}{c}-0.014^{* *} \\
{[0.006]}\end{array}$ & $\begin{array}{c}-0.066^{* * *} \\
{[0.012]}\end{array}$ & $\begin{array}{c}-0.054^{* * *} \\
{[0.010]}\end{array}$ & $\begin{array}{c}0.003 \\
{[0.009]} \\
\end{array}$ & $\begin{array}{c}-0.009 \\
{[0.017]} \\
\end{array}$ & $\begin{array}{c}-0.017 \\
{[0.020]} \\
\end{array}$ \\
\hline 2-Lag share white-collar workers and managers & & & $\begin{array}{c}0.011 \\
{[0.023]}\end{array}$ & & & $\begin{array}{c}0.008 \\
{[0.042]}\end{array}$ \\
\hline 2-Lag share females & & & $\begin{array}{c}0.019 \\
{[0.019]}\end{array}$ & & & $\begin{array}{l}-0.062^{*} \\
{[0.034]}\end{array}$ \\
\hline 2-Lag age & & & $\begin{array}{c}-0.082^{* *} \\
{[0.034]}\end{array}$ & & & $\begin{array}{c}0.067 \\
{[0.057]}\end{array}$ \\
\hline 2-Lag log firm size & & & $\begin{array}{l}0.008^{* *} \\
{[0.003]}\end{array}$ & & & $\begin{array}{l}-0.001 \\
{[0.008]}\end{array}$ \\
\hline Time dummies & yes & yes & yes & yes & yes & yes \\
\hline Observations & 1,386 & 1,386 & 1,386 & 1,386 & 1,386 & 1,386 \\
\hline R-squared & 0.295 & 0.051 & 0.186 & 0.091 & 0.088 & 0.090 \\
\hline Weak identification test (F-value) & & 217.7 & 191.8 & & 217.7 & 191.8 \\
\hline Number of contracts & 198 & 198 & 198 & 198 & 198 & 198 \\
\hline
\end{tabular}


Table 3: Impact of imports on wages and interaction with contracts' skill share

\begin{tabular}{|c|c|c|c|c|c|c|}
\hline & \multicolumn{3}{|c|}{ Log Minimum Wage } & \multicolumn{3}{|c|}{ Log Total Wage } \\
\hline & (1) & $(2)$ & (3) & $(4)$ & (5) & (6) \\
\hline & FE & IVFE & IVFE & FE & IVFE & IVFE \\
\hline 2-Lag log import penetration index & $\begin{array}{c}-0.023^{* * *} \\
{[0.007]}\end{array}$ & $\begin{array}{c}-0.072 * * * \\
{[0.011]}\end{array}$ & $\begin{array}{c}-0.062^{* * *} \\
{[0.010]}\end{array}$ & $\begin{array}{l}-0.007 \\
{[0.010]}\end{array}$ & $\begin{array}{l}-0.017 \\
{[0.017]}\end{array}$ & $\begin{array}{l}-0.029 \\
{[0.019]}\end{array}$ \\
\hline $\begin{array}{l}\text { 2-Lag log import penetration index } * 2 \text {-Lag share } \\
\text { white-collar workers and managers }\end{array}$ & $\begin{array}{c}0.039 * * * \\
{[0.011]} \\
\end{array}$ & $\begin{array}{c}0.094^{* * *} \\
{[0.024]}\end{array}$ & $\begin{array}{l}0.086^{* * *} \\
{[0.023]}\end{array}$ & $\begin{array}{c}0.041 \\
{[0.026]}\end{array}$ & $\begin{array}{l}0.109 * * \\
{[0.045]}\end{array}$ & $\begin{array}{l}0.122 * * * \\
{[0.044]}\end{array}$ \\
\hline 2-Lag share white-collar workers and managers & $\begin{array}{c}0.095^{* * *} \\
{[0.023]}\end{array}$ & $\begin{array}{l}0.192 * * * \\
{[0.042]}\end{array}$ & $\begin{array}{l}0.168^{* * *} \\
{[0.042]}\end{array}$ & $\begin{array}{c}0.055 \\
{[0.068]}\end{array}$ & $\begin{array}{l}0.176^{*} \\
{[0.100]}\end{array}$ & $\begin{array}{l}0.230 * * \\
{[0.094]}\end{array}$ \\
\hline 2-Lag share females & & & $\begin{array}{c}0.012 \\
{[0.017]}\end{array}$ & & & $\begin{array}{c}-0.072 * * \\
{[0.034]}\end{array}$ \\
\hline 2-Lag age & & & $\begin{array}{l}-0.058^{*} \\
{[0.035]}\end{array}$ & & & $\begin{array}{c}0.100 * \\
{[0.059]}\end{array}$ \\
\hline 2-Lag log firm size & & & $\begin{array}{l}0.007 * * \\
{[0.003]}\end{array}$ & & & $\begin{array}{c}-0.001 \\
{[0.008]}\end{array}$ \\
\hline Time dummies & yes & yes & yes & yes & yes & yes \\
\hline Observations & 1,386 & 1,386 & 1,386 & 1,386 & 1,386 & 1,386 \\
\hline R-squared & 0.319 & 0.164 & 0.240 & 0.095 & 0.084 & 0.089 \\
\hline Weak identification test (F-value) & & 31.60 & 34.13 & & 31.60 & 34.13 \\
\hline Number of contracts & 198 & 198 & 198 & 198 & 198 & 198 \\
\hline
\end{tabular}

Table 4: Estimations of Table 2 and 3 with technology controls

\begin{tabular}{|c|c|c|c|c|}
\hline & \multicolumn{2}{|c|}{ Log Minimum Wage } & \multicolumn{2}{|c|}{ Log Total Wage } \\
\hline & (1) & (2) & (3) & $(4)$ \\
\hline & IVFE & IVFE & IVFE & IVFE \\
\hline 2-Lag log import penetration index & $\begin{array}{c}-0.029^{* *} \\
{[0.009]}\end{array}$ & $\begin{array}{c}-0.068^{* * *} \\
{[0.012]}\end{array}$ & $\begin{array}{c}-0.008 \\
{[0.019]}\end{array}$ & $\begin{array}{l}-0.038^{*} \\
{[0.023]}\end{array}$ \\
\hline $\begin{array}{l}\text { 2-Lag log import penetration index*2-Lag share } \\
\text { white-collar workers and managers }\end{array}$ & & $\begin{array}{c}0.111^{* * *} \\
{[0.027]}\end{array}$ & & $\begin{array}{c}0.160 * * * \\
{[0.057]}\end{array}$ \\
\hline 2-Lag log ICT capital over value added & $\begin{array}{c}0.041 \\
{[0.032]}\end{array}$ & $\begin{array}{l}0.087^{* *} \\
{[0.036]}\end{array}$ & $\begin{array}{c}0.104 \\
{[0.067]}\end{array}$ & $\begin{array}{c}0.135^{*} \\
{[0.071]}\end{array}$ \\
\hline 2-Lag share white-collar workers and managers & $\begin{array}{l}-0.002 \\
{[0.023]}\end{array}$ & $\begin{array}{c}0.184^{* * *} \\
{[0.051]}\end{array}$ & $\begin{array}{l}-0.027 \\
{[0.049]}\end{array}$ & $\begin{array}{l}0.254^{* *} \\
{[0.117]}\end{array}$ \\
\hline 2-Lag share females & $\begin{array}{c}0.003 \\
{[0.021]}\end{array}$ & $\begin{array}{c}0.001 \\
{[0.020]}\end{array}$ & $\begin{array}{l}-0.078 * * \\
{[0.036]}\end{array}$ & $\begin{array}{l}-0.089 * * \\
{[0.037]}\end{array}$ \\
\hline 2-Lag age & $\begin{array}{c}-0.119 * * * \\
{[0.033]}\end{array}$ & $\begin{array}{l}-0.076^{* *} \\
{[0.037]}\end{array}$ & $\begin{array}{c}0.025 \\
{[0.062]}\end{array}$ & $\begin{array}{c}0.073 \\
{[0.066]}\end{array}$ \\
\hline 2-Lag log firm size & $\begin{array}{c}0.008^{* *} \\
{[0.004]} \\
\text { yes }\end{array}$ & $\begin{array}{c}0.009 * * \\
{[0.004]} \\
\text { yes }\end{array}$ & $\begin{array}{c}0.001 \\
{[0.008]} \\
\text { yes }\end{array}$ & $\begin{array}{c}0.001 \\
{[0.009]} \\
\text { yes }\end{array}$ \\
\hline Observations & 1,386 & 1,386 & 1,386 & 1,386 \\
\hline R-squared & 0.104 & 0.101 & 0.055 & 0.027 \\
\hline Weak identification test (F-value) & 18.91 & 15.58 & 18.91 & 15.58 \\
\hline Number of contracts & 198 & 198 & 198 & 198 \\
\hline
\end{tabular}


Figure 1

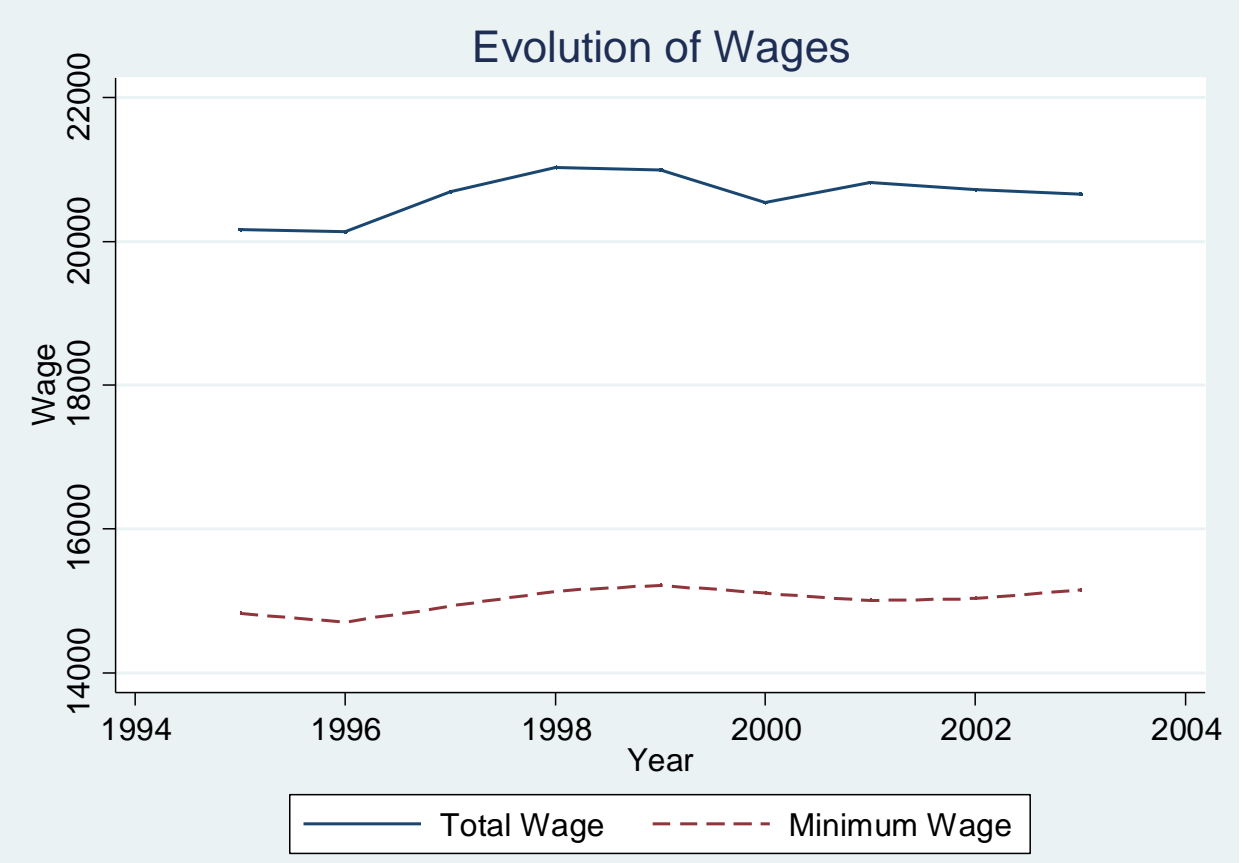

Notes: Annual mean of real wages weighted by the time-average number of individuals within each contract-occupation.

\section{Figure 2}

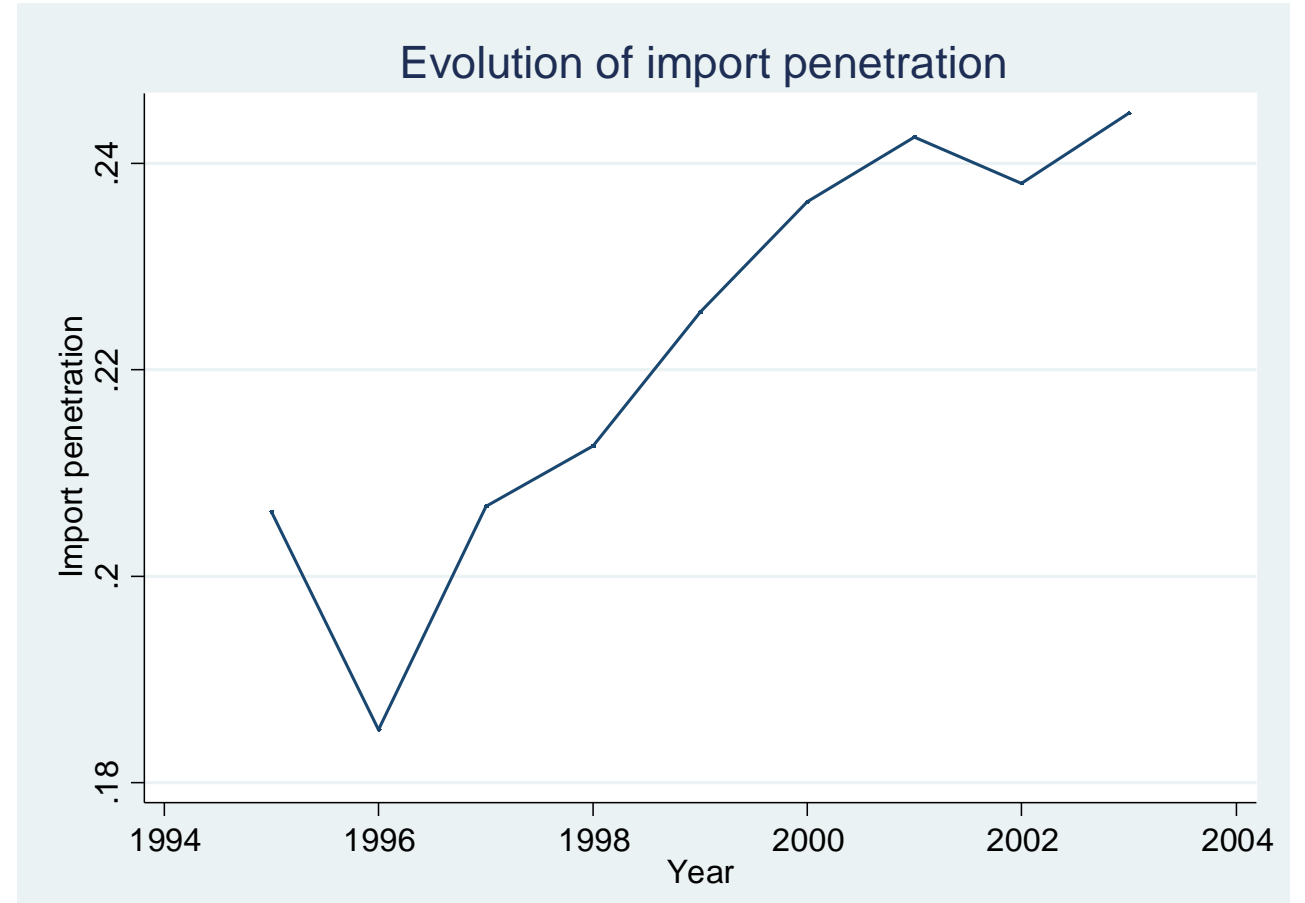

Note: Annual mean of Import Penetration weighted by the time-average number of individuals within each contract. 


\section{Figure 3}

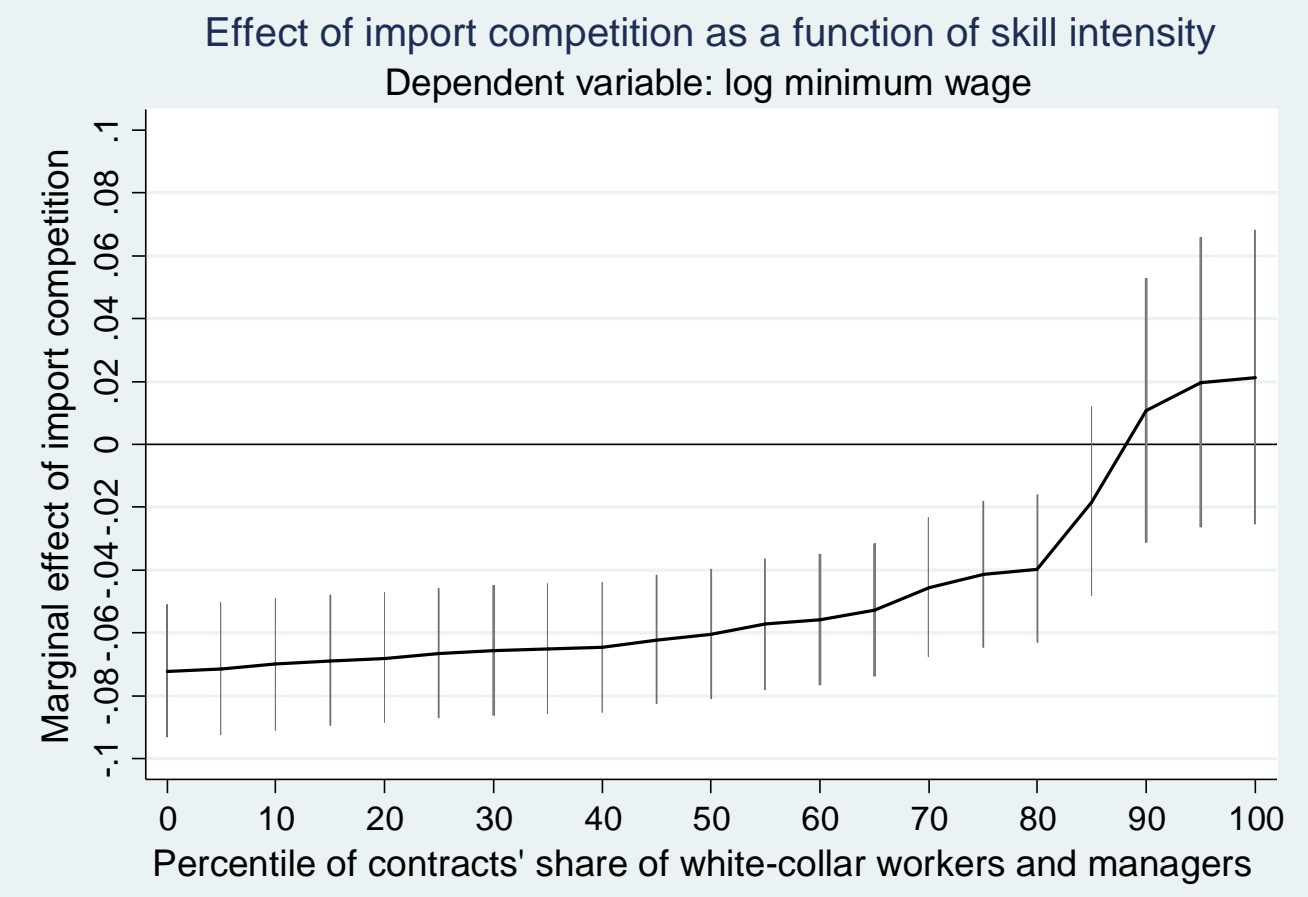

Note: $95 \%$ confidence intervals reported. Elasticities computed using coefficient estimates from column (2) of Table 3.

\section{Figure 4}

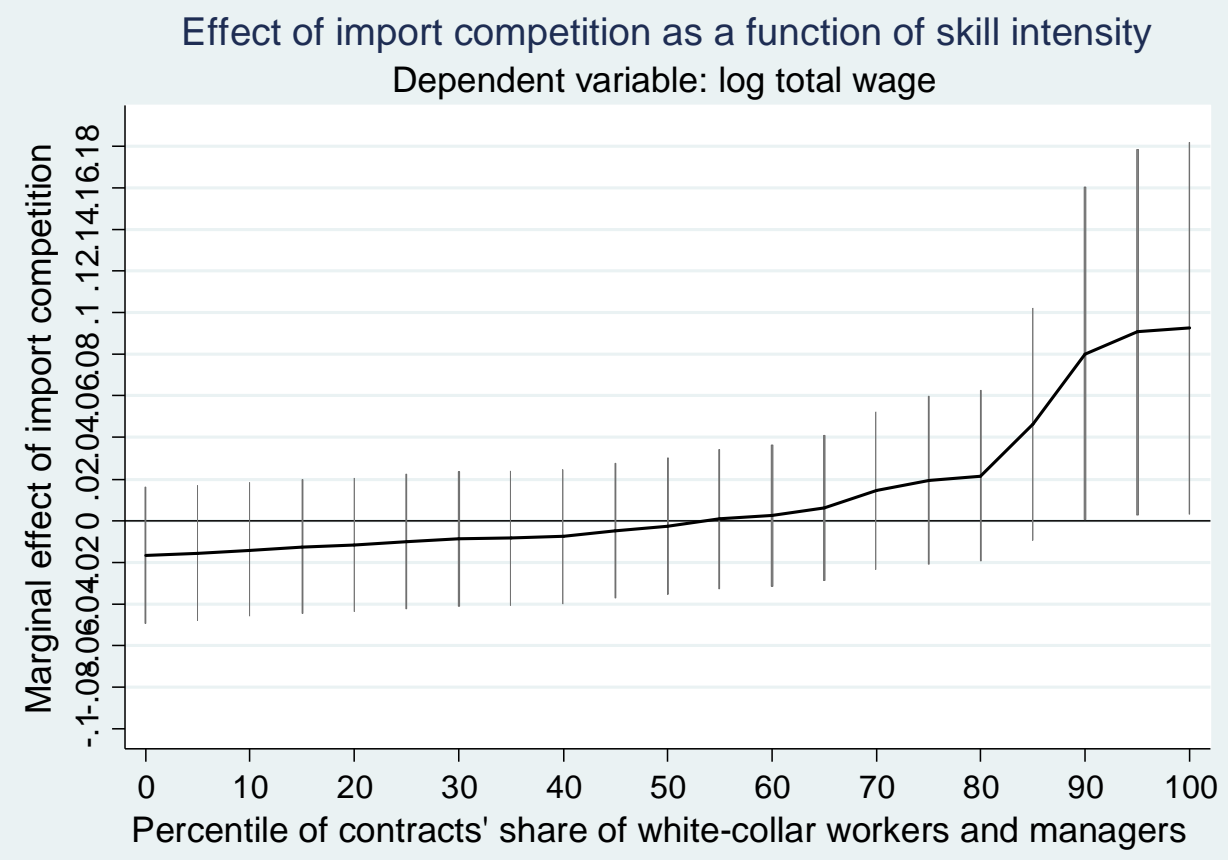

Note: $95 \%$ confidence intervals reported. Elasticities computed using coefficient estimates from column (5) of Table 3. 


\section{Appendix}

\begin{tabular}{lrr}
\hline \multicolumn{2}{l}{ Table A1: Distribution of contracts by sector (3-digit level) } \\
\hline Number of sectors & $\mathbf{1 9 9 5}$ & $\mathbf{2 0 0 3}$ \\
\hline 1 & $\mathbf{0}$ & $\mathbf{\%}$ \\
Between 2 and 3 & 9.6 & 9.09 \\
Between 4 and 6 & 12.63 & 14.65 \\
Between 7 and 10 & 15.66 & 23.24 \\
Between 11 and 20 & 16.67 & 13.14 \\
Over 20 & 30.33 & 21.75 \\
Number of contracts & 15.11 & 18.13 \\
\hline
\end{tabular}

Table A2: Impact of imports on wages. One-year lag specification

\begin{tabular}{|c|c|c|c|c|c|c|}
\hline & \multicolumn{3}{|c|}{ Log Minimum Wage } & \multicolumn{3}{|c|}{ Log Total Wage } \\
\hline & (1) & $(2)$ & (3) & $(4)$ & $(5)$ & $(6)$ \\
\hline & FE & IVFE & IVFE & FE & IVFE & IVFE \\
\hline 1-Lag log import penetration index & $\begin{array}{l}-0.013 \\
{[0.009]}\end{array}$ & $\begin{array}{c}-0.079 * * * \\
{[0.018]}\end{array}$ & $\begin{array}{c}-0.065^{* * *} \\
{[0.015]}\end{array}$ & $\begin{array}{c}0.002 \\
{[0.010]}\end{array}$ & $\begin{array}{c}-0.024 \\
{[0.016]}\end{array}$ & $\begin{array}{c}-0.022 \\
{[0.017]}\end{array}$ \\
\hline \multirow[t]{2}{*}{ 1-Lag share white-collar workers and managers } & & & 0.028 & & & 0.067 \\
\hline & & & [0.029] & & & [0.053] \\
\hline \multirow[t]{2}{*}{ 1-Lag share females } & & & 0.014 & & & $-0.125^{* * *}$ \\
\hline & & & [0.020] & & & [0.039] \\
\hline \multirow[t]{2}{*}{ 1-Lag age } & & & $-0.081^{* *}$ & & & 0.018 \\
\hline & & & {$[0.039]$} & & & {$[0.050]$} \\
\hline \multirow[t]{2}{*}{ 1-Lag log firm size } & & & $0.009^{* *}$ & & & $0.018^{* *}$ \\
\hline & & & {$[0.004]$} & & & [0.008] \\
\hline Time dummies & yes & yes & yes & yes & yes & yes \\
\hline Observations & 1,584 & 1,584 & 1,584 & 1,584 & 1,584 & 1,584 \\
\hline R-squared & 0.400 & 0.167 & 0.286 & 0.147 & 0.137 & 0.158 \\
\hline Weak identification test (F-value) & & 277.5 & 255.0 & & 277.5 & 255.0 \\
\hline Number of contracts & 198 & 198 & 198 & 198 & 198 & 198 \\
\hline
\end{tabular}

Standard errors clustered at contract-occupation level in parentheses ${ }^{* * *} \mathrm{p}<0.01,{ }^{* *} \mathrm{p}<0.05,{ }^{*} \mathrm{p}<0.1$. 
Table A3: Impact of imports on wages. Standard errors clustered by main contract

\begin{tabular}{|c|c|c|c|c|c|c|}
\hline & \multicolumn{3}{|c|}{ Log Minimum Wage } & \multicolumn{3}{|c|}{ Log Total Wage } \\
\hline & (1) & (2) & (3) & (4) & (5) & (6) \\
\hline & $\overline{\mathrm{FE}}$ & IVFE & IVFE & $\overline{\text { FE }}$ & IVFE & IVFE \\
\hline 2-Lag log import penetration index & $\begin{array}{c}-0.014 \\
{[0.010]}\end{array}$ & $\begin{array}{c}-0.066^{* * *} \\
{[0.023]}\end{array}$ & $\begin{array}{c}-0.054^{* * *} \\
{[0.018]}\end{array}$ & $\begin{array}{c}0.003 \\
{[0.011]}\end{array}$ & $\begin{array}{c}-0.009 \\
{[0.018]}\end{array}$ & $\begin{array}{l}-0.017 \\
{[0.022]}\end{array}$ \\
\hline 2-Lag share white-collar workers and managers & & & $\begin{array}{c}0.011 \\
{[0.025]}\end{array}$ & & & $\begin{array}{c}0.008 \\
{[0.046]}\end{array}$ \\
\hline 2-Lag share females & & & $\begin{array}{c}0.019 \\
{[0.016]}\end{array}$ & & & $\begin{array}{l}-0.062 \\
{[0.039]}\end{array}$ \\
\hline 2-Lag age & & & $\begin{array}{l}-0.082^{*} \\
{[0.043]}\end{array}$ & & & $\begin{array}{c}0.067 \\
{[0.063]}\end{array}$ \\
\hline 2-Lag log firm size & & & $\begin{array}{c}0.008 \\
{[0.005]}\end{array}$ & & & $\begin{array}{c}-0.001 \\
{[0.009]}\end{array}$ \\
\hline Time dummies & yes & yes & yes & yes & yes & yes \\
\hline Observations & 1,386 & 1,386 & 1,386 & 1,386 & 1,386 & 1,386 \\
\hline R-squared & 0.295 & 0.051 & 0.186 & 0.091 & 0.088 & 0.090 \\
\hline Weak identification test (F-value) & & 89.38 & 80.90 & & 89.38 & 80.90 \\
\hline Number of contracts & 198 & 198 & 198 & 198 & 198 & 198 \\
\hline
\end{tabular}

Table A4: Impact of imports on wages. Estimates weighted by number of worked weeks

\begin{tabular}{|c|c|c|c|c|c|c|}
\hline & \multicolumn{3}{|c|}{ Log Minimum Wage } & \multicolumn{3}{|c|}{ Log Total Wage } \\
\hline & (1) & (2) & (3) & (4) & (5) & (6) \\
\hline & FE & IVFE & IVFE & FE & IVFE & IVFE \\
\hline 2-Lag log import penetration index & $\begin{array}{c}-0.014^{* *} \\
{[0.006]}\end{array}$ & $\begin{array}{c}-0.065^{* * *} \\
{[0.012]}\end{array}$ & $\begin{array}{c}-0.054^{* * *} \\
{[0.010]}\end{array}$ & $\begin{array}{c}0.007 \\
{[0.010]}\end{array}$ & $\begin{array}{c}-0.010 \\
{[0.015]}\end{array}$ & $\begin{array}{c}-0.012 \\
{[0.017]}\end{array}$ \\
\hline 2-Lag share white-collar workers and managers & & & $\begin{array}{c}0.015 \\
{[0.023]}\end{array}$ & & & $\begin{array}{c}0.038 \\
{[0.036]}\end{array}$ \\
\hline 2-Lag share females & & & $\begin{array}{c}0.018 \\
{[0.019]}\end{array}$ & & & $\begin{array}{c}-0.038 \\
{[0.032]}\end{array}$ \\
\hline 2-Lag age & & & $\begin{array}{c}-0.079 * * \\
{[0.035]}\end{array}$ & & & $\begin{array}{c}0.060 \\
{[0.046]}\end{array}$ \\
\hline 2-Lag log firm size & & & $\begin{array}{l}0.009^{* *} \\
{[0.004]}\end{array}$ & & & $\begin{array}{c}0.008 \\
{[0.007]}\end{array}$ \\
\hline Time dummies & yes & yes & yes & yes & yes & yes \\
\hline Observations & 1,386 & 1,386 & 1,386 & 1,386 & 1,386 & 1,386 \\
\hline R-squared & 0.300 & 0.067 & 0.192 & 0.077 & 0.071 & 0.075 \\
\hline Weak identification test (F-value) & & 224.9 & 201.2 & & 224.9 & 201.2 \\
\hline Number of contracts & 198 & 198 & 198 & 198 & 198 & 198 \\
\hline
\end{tabular}




\section{UBIREA}

Institut de Recerca en Economia Aplicada Regional i Públic

Research Institute of Applied Economics

WEBSITE: www.ub-irea.com·CONTACT: irea@ub.edu

\section{$\mathrm{AQR}$}

Grup de Recerca Anàlisi Quantitativa Regional

Regional Quantitative Analysis Research Group

WEBSITE: www.ub.edu/aqr/•CONTACT: aqr@ub.edu

\section{Universitat de Barcelona}

Av. Diagonal, 690 • 08034 Barcelona 